\title{
THE COLLECTION OF ANABAPTIST (HUTTERITE) CERAMICS IN THE MORAVIAN MUSEUM IN BRNO ${ }^{1}$
}

\author{
Alena KalinovÁ \\ Moravské zemské muzeum \\ Zelný trh 6, 65937 Brno, Czech Republic \\ E-mail: akalinova@mzm.cz
}

\begin{abstract}
The Anabaptists, who started to settle in Moravia after 1526, brought with them the production of faience. They were concentrated mainly in the demesnes of Southern Moravia (current districts of Břeclav, Hodonín, Uherské Hradiště and Znojmo), but after 1620 as non-Catholics, the Anabaptists had to leave. They went mostly to the neighbouring Kingdom of Hungary, today the western region of Slovakia where they continued to produce faience. After the Anabaptist community disintegrated in the last quarter of the $17^{\text {th }}$ century, the production of faience was taken over by individual craftsmen.

The Moravian Museum in Brno holds one of the most representative collections of Anabaptist faience in the Czech Republic. Its origin dates back to the early years after the foundation of the Francis Museum, the predecessor of today's Moravian Museum. At present, it comprises around 250 items.

Keywords: ceramics, faience, Moravia, Slovakia, $16^{\text {th }}-18^{\text {th }}$ centuries, collection, Moravian Museum
\end{abstract}

An important contribution of the Anabaptists to European cultural development is their production of faience ceramics, which have for decades attracted the attention of researchers and collectors. Alongside archive materials, the principal source of our knowledge is the products themselves, which became part of museum, chateau and private collections mostly within the territory where the Anabaptist craftsmen worked in the $16^{\text {th }}$ and $17^{\text {th }}$ centuries. The most extensive collections of Anabaptist faience are therefore found in Czech, Slovakian, Austrian and, in particular, Hungarian holdings.

The Anabaptists were followers of the religious reformers, whose ideas spread from Switzerland to the neighbouring countries. Because of their radical religious and social ideas, shortly after their establishment in 1525 they were consistently persecuted and banned from Switzerland and they also had to leave Southern Germany, Tyrol and

${ }^{1}$ This article was supported by the Ministry of Culture of the Czech Republic through institutional financing of the long-term conceptual development of the research institution (the Moravian Museum, MK000094862). 
Northern Italy. They found refuge in the religiously tolerant environment of Southern Moravia.

The centre of the first Moravian Anabaptists was established in Mikulov in 1526. At that time, the first Anabaptist communities began to form within the Moravian territory and they were continuously extended with new waves of migration. Behind each of the waves stood the particular personality of a thinker or preacher who, in their original way, explained some of the teachings of the dogma. The Moravian Anabaptist community, connected mainly with the Tyrolean native Jakob Hutter $(+1536)$, consisted (at its peak between 1565-1592) of more than fifty colonies distributed in the area between Brno, Znojmo, Břeclav and Uherské Hradiště, with a total population amounting to probably 12,000-15,000 people. $^{2}$ The Hutterites formed a closed community which, except for economic relations, did not come into contact with the local environment. The Moravian nobility gladly received the Anabaptists on their farms as people who were highly sophisticated masters of all the important crafts. Hard-working and reliable, they became welcome workers even in the noble houses, where they were often employed as property managers or stewards. The brethren founded communal farms known as Bruderhof or Haushaben that included numerous workshops specializing mainly in cloth-weaving and other crafts, among which cutlery making, clock making, leather and mother-of-pearl processing were highly esteemed. Among the many successfully plied trades it was above all ceramic production and the making of faience that brought the Anabaptists fame, demonstrating their excellent skills and bringing considerable economic profit to the Hutterite community. The main activity of the Anabaptist ceramicists was a broad range of pottery products, which were an indispensable part of the everyday life of society in that period. Faience is believed to have been produced in Moravia from the 1580s onwards.

The defeat of the Estates army at the Battle of White Mountain meant the advent of forced re-Catholicization. An imperial patent of 1622 ordered all non-Catholics to convert to the Catholic religion within four weeks or otherwise they would be forced to leave their houses. Apart from a small renegade element the Anabaptists moved to Hungary, to the neighbouring West Slovakian territory, leaving vast assets in Moravia. Anabaptist farms had already been established earlier in the Hungarian Kingdom, today south-west of Slovakia-e.g. in Sobotiště (Szobotist, Hungary) (1546), Vel'ké Leváre (Nagylévárd, Hungary) (1588), Brodské (Broczkó, Hungary), Moravský Sväty Ján (Morvaszentjános, Hungary). Here, and in the newly established colonies such as Košolná (Kosolna, Hungary), Dechtice (Dejte, Hungary), Čachtice (Csejte, Hungary), Častá (Cseszte, Hungary), Chtelnica (Vittenc) and Farkašín (today Vlčkovce, former Farkashida, Hungary) they continued their way of life. Some Anabaptists left from 1621 to go to Transylvania, under the protection of Gábor Bethlen, where their kin had appeared shortly before these events. ${ }^{3}$ During

\footnotetext{
${ }^{2}$ See PAJER 2006: 10.

${ }^{3}$ The remaining faithful Anabaptists endured a cruel fate. Their persecution continued well into the $18^{\text {th }}$ century. Under the reign of Maria Theresa, as part of the re-Catholicization drive, they had to leave Transylvania for southern Romania (Wallachia), and from there many wandered via Poland and Moldavia to the Ukraine and finally to North America. It is interesting to note that the descendants of the Anabaptists who left Europe in the $19^{\text {th }}$ century, continue to live even today in their traditional communities in the USA and Canada and make a living mainly by agriculture.
} 
the following decades, however, certain events within the brethren community gradually began to erode the established order and to loosen the formerly tight bonds. This process was intensified by a series of unfortunate events which hit the Anabaptist community at that time and, as a result, the original collective in Vel'ké Leváre was dissolved in 1685 and communal ownership was abandoned, as was soon to be the case in the remaining Anabaptist communities in the Hungarian Kingdom, today Slovakia.

In most Anabaptist sites, the craftsmen started to ply their trade independently, which greatly contributed to their full assimilation into the local population. From the end of the $17^{\text {th }}$ century some of the ceramicists found a home in Moravia, giving rise to new centres of folk faience production (Ždánice, Nové Hvězdlice, Vyškov, Bučovice, Olomouc, Šternberk, Valašské Meziříčí, Ivančice, Velká Bíteš), flourishing mainly in the second half of the $18^{\text {th }}$ and the first half of the $19^{\text {th }}$ century.

The Moravian Museum in Brno holds one of the most representative collections of Anabaptist faience in the Czech Republic. Its origin dates back to the early years after the foundation of the Francis Museum, the predecessor of today's Moravian Museum. In December 1819, a year after the museum's foundation, a record was made in the oldest inventory of a gift of three faience plates from the Ursuline convent in Brno and a majolica bottle given by the vicar of Rouchovany; further new gifts of Anabaptist faience were recorded in 1821 and 1824. The items can be identified in today's collection by their original inventory numbers. Many of the later acquisitions were originally in private collections, from which they passed, over time, to the museum to represent important elements in the development of one of the major periods in the history of local ceramic production. Purchased from the province's budget in 1904 and 1912, a significant number of the items in the present museum holdings were transferred to the museum as part of the extensive collections of the journalist, collector and ethnography researcher in Moravian Slovakia, František Kretz (1859-1929). The very first set purchased contained the oldest dated item of the present collection-a tazza with openwork sides with the date 1629 (Fig. 2); two similar examples are found in museums abroad (Fig. 6). ${ }^{4}$ Systematic additions to the collection were made especially after World War II, when the museum acquired the results of the collecting activities, among others, of František Gryc from Brno, Oldřich Hrstka from Ostrava, Ctibor Sonevend from Kyjov and, most importantly, in 1967, an excellent set by the composer Ladislav Vycpálek from Prague. ${ }^{5}$ Further examples found their way into the museum through individual purchases, the last item-a bowl from the beginning of the $18^{\text {th }}$ century-was purchased in 1987.

The collection is of a representative nature in all respects. From the temporal point of view, almost two-thirds of the museum collection are objects made in the final phase of the development of Anabaptist faience, roughly between 1690 and 1730. In terms of the product range we observe a predominance of flat ware. From the earliest production stage up to 1600 only a torso of a small bowl has survived (Fig. 3), and from the first quarter of the $17^{\text {th }}$ century an incomplete albarello (probably from 1610, Fig. 4) and a

\footnotetext{
${ }^{4}$ See Pajer 2006: 148-150.

${ }^{5}$ Cf. articles by Kalinová 1984, 1985.
} 
white-glazed four-sided bottle (Fig. 5). ${ }^{6}$ The oldest dated item is a tazza with openwork sides from 1629 (Fig. 6), which may have already been produced in one of the workshops in the Kingdom of Hungary, today Western Slovakia. From the period 1620-1650 a total of 10 items survive in the collection and 9 products from the following two decades 1650-1670. Ten exhibits originate from the years 1670-1680 and 17 items from the next decade 1680-1690. The earlier period is represented mainly by jugs (Fig. 7), while from the third quarter of the $17^{\text {th }}$ century we have mostly plates and bowls (Fig. 14). In terms of the product range, the collection of the Moravian Museum embraces virtually all the known products-including a candle-stick (Fig. 18), a tankard (Fig. 30), an ink pot and tiles (Fig. 17) - and in jugs and flat ware also different variants in shape. The range of the decorative styles is equally well represented.

During research into the museum collection it has been shown that important impulses for its development were given mainly by the excavation of the Anabaptist farms. The Moravian Museum became involved in these activities as early as the end of the $19^{\text {th }}$ century. Josef Hladík, co-founder of the Museum Society in Brno and, from 1890, curator of the prehistory collection, handed over to the Ethnographic Department of the Francis Museum remarkable shard material from test digs made in 1891 and 1892 in Podivín, in the area called Habánice. The finds of faience shards, among which was the torso of a bowl from the time before 1600 (Fig. 3), ${ }^{7}$ confirmed the existence of Anabaptist ceramicists on a site previously mentioned only in archive sources. The main activities in this field, however, were associated with the name of PhDr. František Pospíšil (1885-1958), who was head of the Ethnography Department of the Moravian Museum in Brno from 1920 to 1945. Pospíšil was well aware of the cultural, historical and scientific significance of the museum's ceramic collection and established close working contacts with an expert in folk faience, the ceramicist and collector Herrman Landsfeld (1899-1984), then active in Modra in Western Slovakia. It was he who, in the first half of the 1930s, started pioneering excavations of Anabaptist colonies in Western Slovakia, whose ceramic tradition later laid the foundations for the local production of folk faience. In the 1920s, Landsfeld greatly contributed to organizing the ceramics collection of the Ethnography Department, which he classified by workshops and its installation in the permanent museum exhibition in the Dietrichstein Palace. The Moravian Museum also acquired part of Landsfeld's ceramic finds. During World War II, the museum began to carry out its own excavations and research into archive evidence. Pospíšil probably intended to build a documentation centre of Moravian Anabaptists, he brought together specialized literature and archive materials and arranged for the collection items to be photographed. Unfortunately, with the exception of a few archive records, no tangible evidence of this activity has survived and the acquired shard material is still missing. ${ }^{8}$

\footnotetext{
${ }^{6}$ An overview of the earliest surviving faiences of Moravian origin is given in PAJER 2011.

${ }^{7}$ Published for the first time in Černohorský 1931, 40, Fig.1; PAJer 2006, 139. Kept in the EÚ MZM collection, Inv. n. KER 24557.

${ }^{8}$ Cf. e.g. Kalinová 2008. Recently a number of new and revision investigations in Moravian sites were carried out under the supervision of Jiří Pajer, yielding many essential findings that substantially expanded our previous idea of the life of the Hutterite community and its ceramic production.
} 
In the 1950s, an important impetus for research into the production of Hutterite faience was given by the Museum of Applied Arts in Brno, carrying out its own excavations, for example in Vacenovice (Hodonín district). Their work resulted in a large exhibition of Hutterite faience at the turn of 1955 and 1956, accompanied by the publication of two catalogues $(1955,1961)$. This occasion was also used by the Moravian Museum to present its excellent collection there as it did later at a prestigious exhibition in Bratislava (1976), subsequently shown in Prague (1978) and particularly at the most extensive exhibition to date of Hutterite faience from Czech collections held by the Prague Museum of Decorative Arts and the Brno Moravian Gallery in 1981-1982 in Prague and Brno.

The collection of Anabaptist faience in the Moravian Museum in Brno is, alongside the collections of the Museum of Decorative Arts and the National Museum in Prague and the Moravian Gallery in Brno, one of the most important sets in the country and provides one of the principal sources for ceramological research into the faience production of the $16^{\text {th }}-18^{\text {th }}$ centuries.

\section{LITERATURE}

ČERNOHORSKY, Karel

1931: Počátky habánských fajánsi [Early Habaner Faience]. Zvláštní otisk z Věstníku Zemského muzea v Opavě (Sborník E. W. Brauna). Opava.

1952: K počátkům fajansové výroby na území Československa [On Early Faience Production on the Territory of Czechoslovakia]. Český lid 39, 21-28.

1941: Moravská lidová keramika [Moravian Folk Ceramics]. Nakladatelství J. Otto, Praha.

Horváth, J. Eugene - Krisztinkovich, Maria H.

2005: A History of Haban Ceramics. A Private View. Vancouver.

KaLESNÝ, František

1981: Habáni na Slovensku [The Habaner in Slovakia]. Tatran, Bratislava.

KaLINOvÁ, Alena

1984: Počátky národopisného studia lidového umění a sbírka keramiky v Moravském muzeu [Early Ethnographic Studies of Folk Art and the Ceramic Collection of the Moravian Museum]. Ćasopis Moravského muzea. Vědy společenské 69, 231-238.

1985: K vývoji sbírky keramiky v Moravském muzeu [Notes on the Development of the Ceramic Collection in the Moravian Museum]. Časopis Moravského muzea. Vědy společenské 70, 269-274.

2008: Výzkum novokřtěnské (habánské) keramiky v Moravském zemském muzeu před rokem 1945 [Research into Anabaptist (Hutterite) Ceramics in the Moravian Museum before 1945]. In: H. DvoŘÁKovÁ (ed.): Hanák na Pacifiku. Zapomenutá osobnost Františka Pospíšila. [A Man from Haná on the Pacific Coast. The forgotten figure of František Pospíšil.] Moravské zemské museum, Brno, 115-127.

KudĚLkovÁ, Alena - ZeminovÁ, Milena

1961: Habánská fajáns v Uměleckoprůmyslovém muzeu v Praze a Brně [Habaner Faience in the Museum of Decorative Arts in Prague and Brno]. Uměleckoprůmyslové muzeum, Praha.

KybalovÁ, Jana

1995: Keramická sbírka Hugo Vavrečky [Ceramic Collection of Hugo Vavrečka]. Kentaur, Praha.

KyBAlovÁ, Jana - NovotnÁ, Jarmila

[1981:] Habánská fajáns 1590-1730 [Habaner Faience 1590-1730]. Catalogue of an exhibition held at the Royal Summer House at Prague and in Dům umění in Brno. Praha-Brno.

LANDSFELD, Heřman

1950: Lidové hrnčírství a džbánkařství. Besedy o řmesle džbánkařském, hrnčriřském a kamnařském [Folk pottery. Talks about the faience-, pottery- and stove-craft]. Orbis, Praha. 


\section{PAJER, Jiří}

2001: Novokřtěnské fajánse ze Strachotína [Anabaptist Faience from Strachotín]. Regionální muzeum, Mikulov.

2006: Studie o novokřtěncích [Studies of Anabaptists]. Etnos, Strážnice.

2011: Anabaptist Faience from Moravia 1593-1620. Catalogue of documents from institutional and private collections. Etnos, Strážnice.

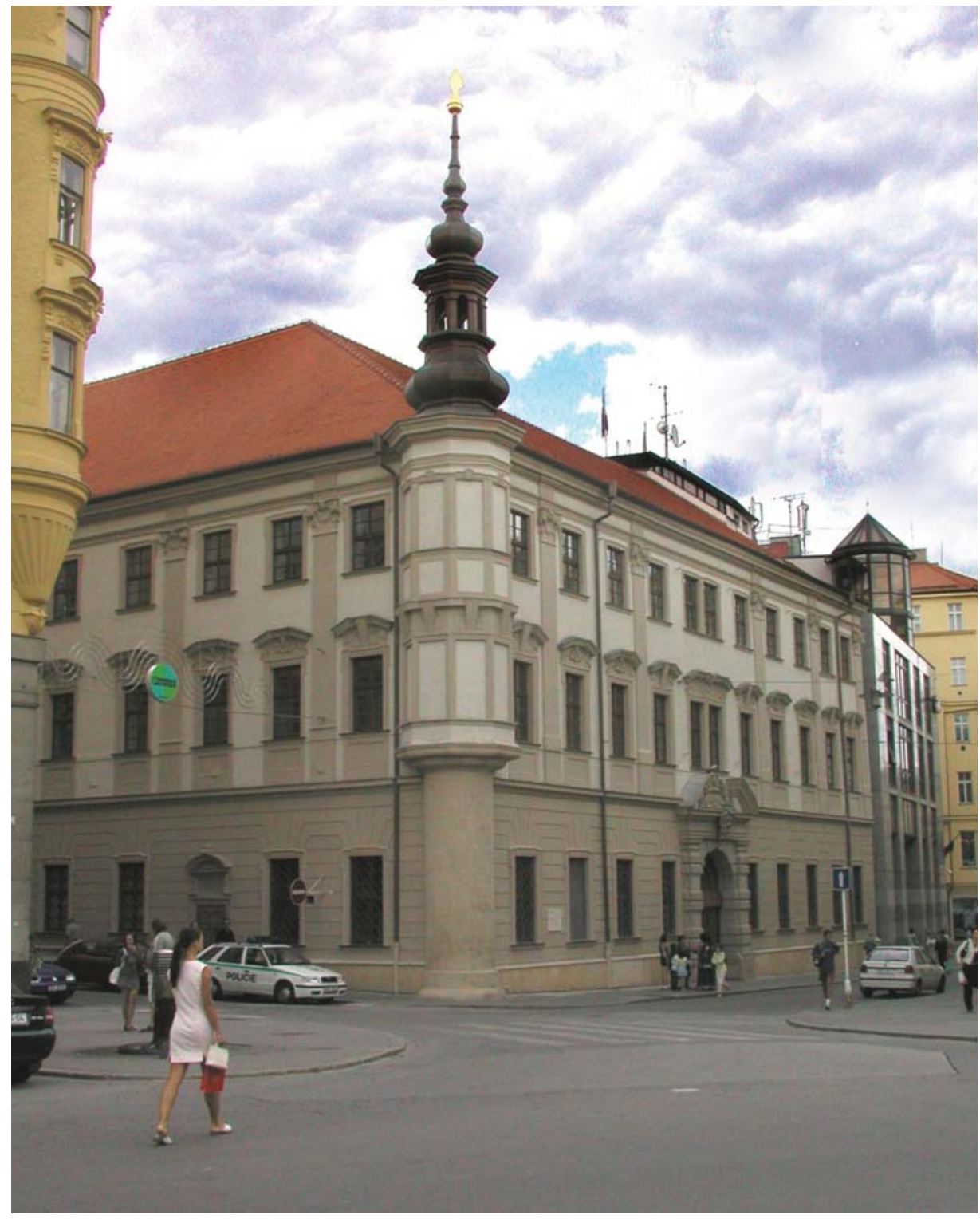

Fig. 1. The Ethnographic Institute of the Moravian Museum in Brno, housed in the Noble Women's Palace dating from the second half of the $17^{\text {th }}$ century. 


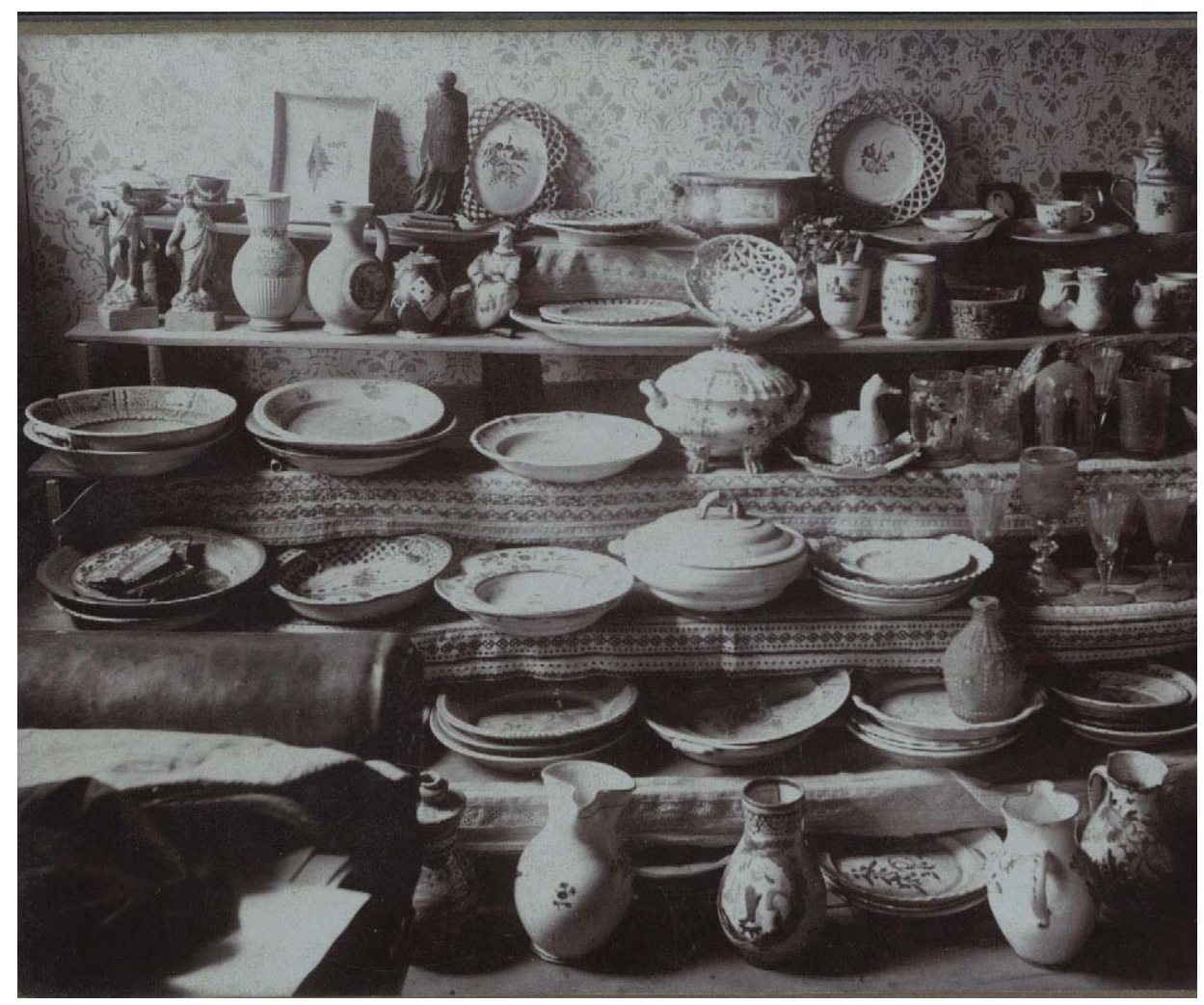

Fig. 2. Set of faience of the collector František Kretz from Uherské Hradiště, around 1900.

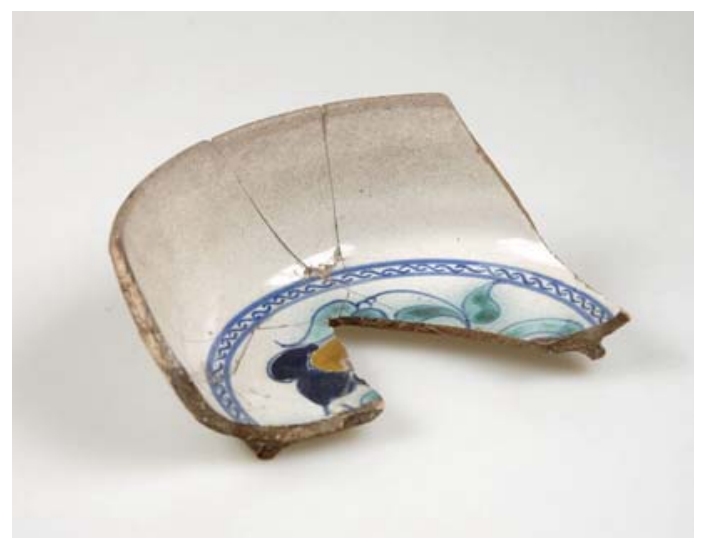

Fig. 3. Torso of a small bowl from the end of the $16^{\text {th }}$ century, found by J. Hladík in 1891-1892 in Podivín (Břeclav district). Inv. n. KER 24557. 


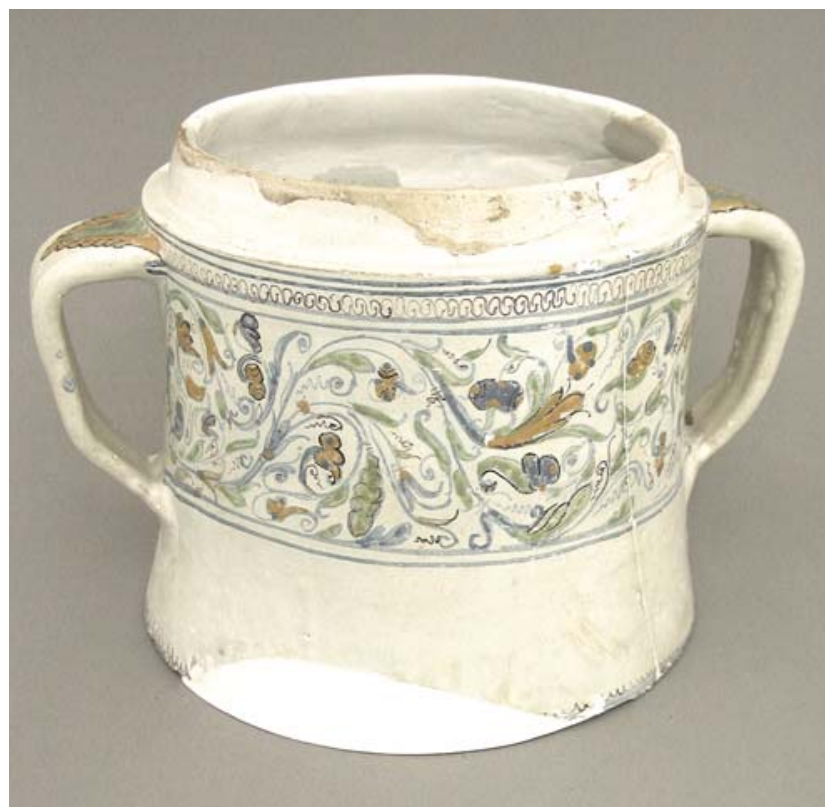

Fig. 4. Torso of an albarello from 1610, probably from a workshop in Vacenovice (Hodonín district). Inv. n. KER 20257.

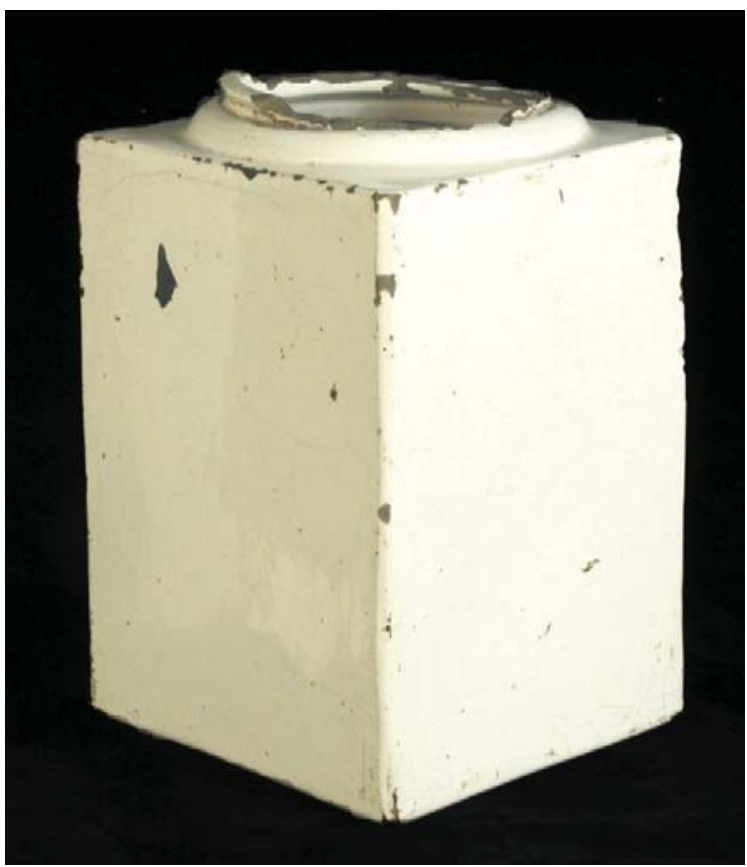

Fig. 5. Four-sided bottle, first quarter of the $17^{\text {th }}$ century. Inv. n. KER 20495. 
a)

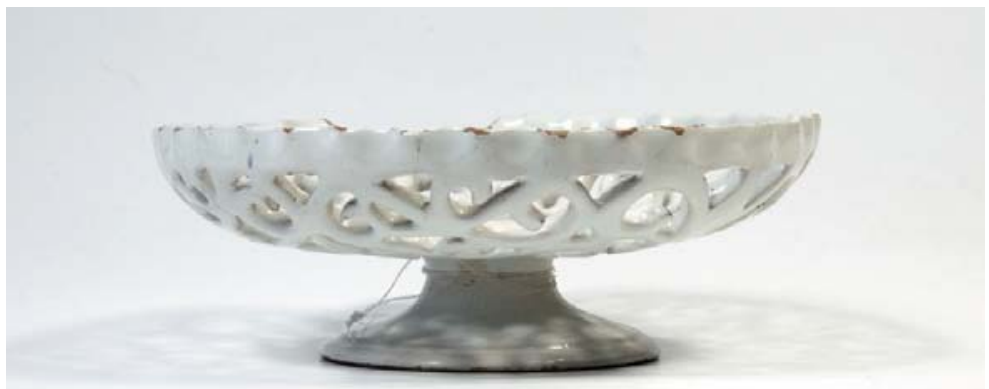

b)

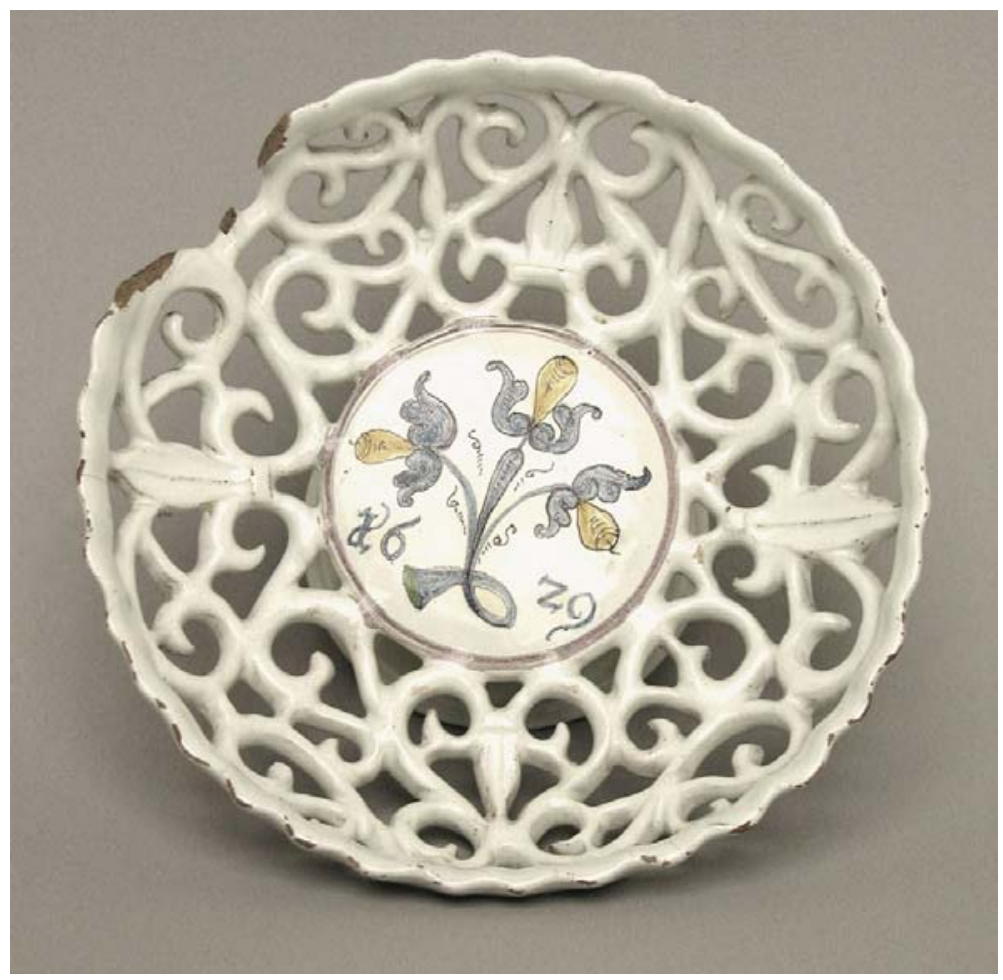

Fig. 6 a , b. Tazza with openwork sides from 1629. Inv. n. KER 20408. 


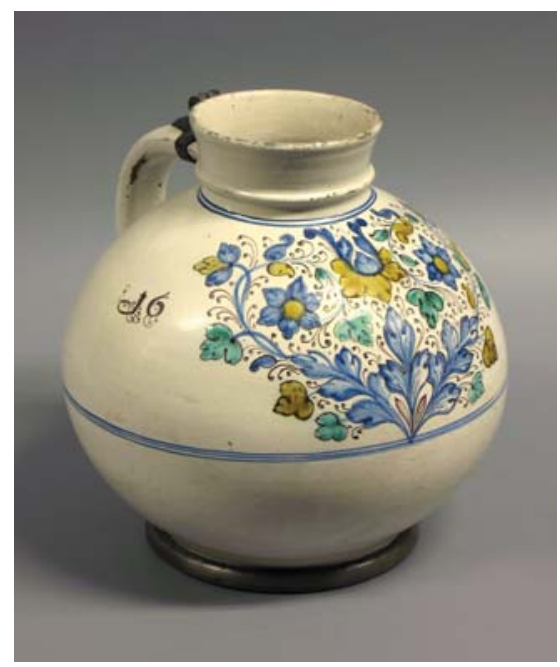

Fig. 7. Jug with a floral motif from 1635. Inv. n. KER 20454.

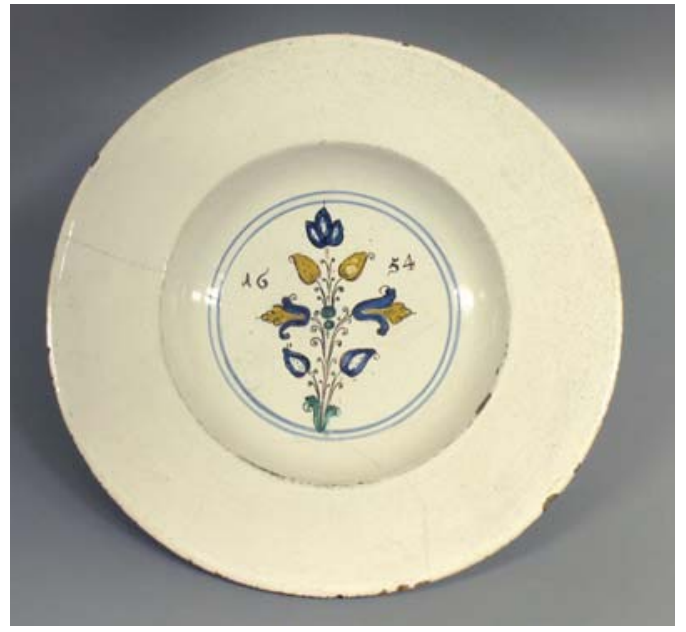

Fig. 8. Bol from 1654. Inv. n. KER 20395.

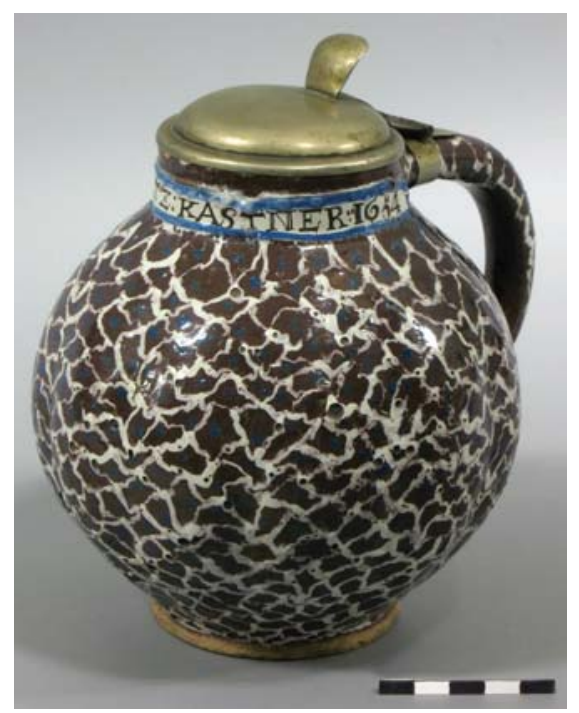

Fig. 9, Ribbed jug with manganese glazing, scale decor and the inscription: FRANTZ: KASTNER: 1654 on the neck. Inv. n. KER 26851 


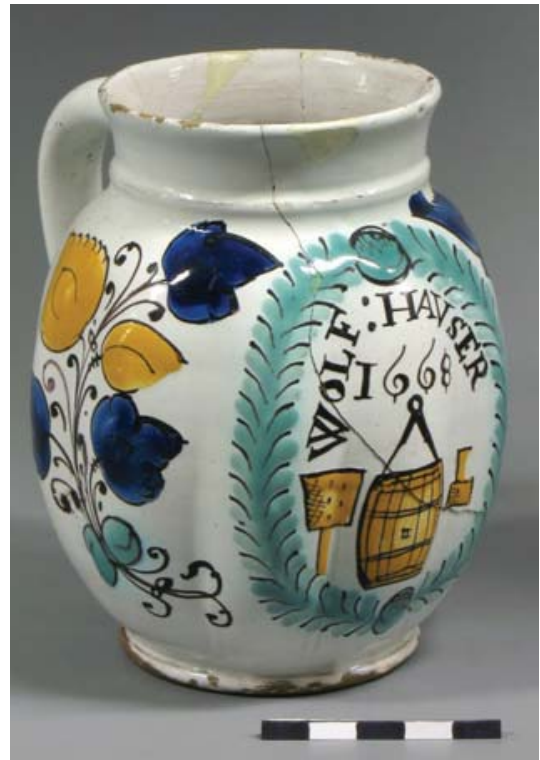

Fig. 10. Jug with the inscription WOLF: HAVSER 1668 and a cooper's emblem. Inv. n. KER 20457.

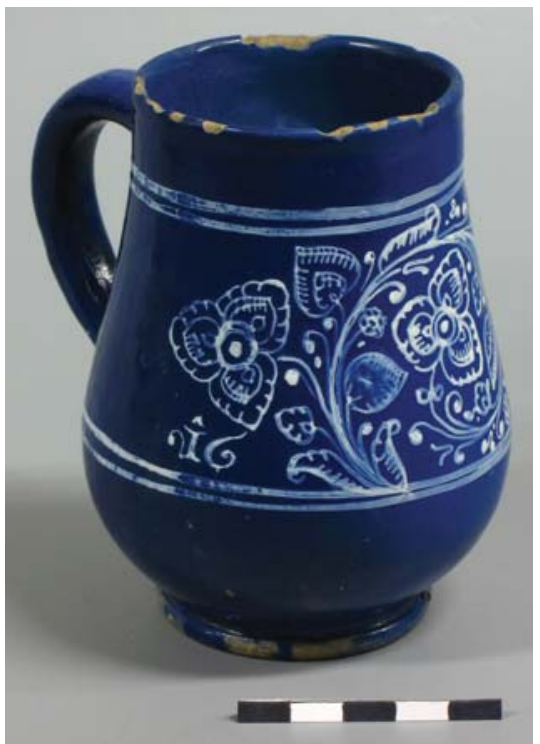

Fig. 12. Jug with cobalt glazing and white floral décor from 1675, with a double side and bottom. Inv. n. KER 24684.

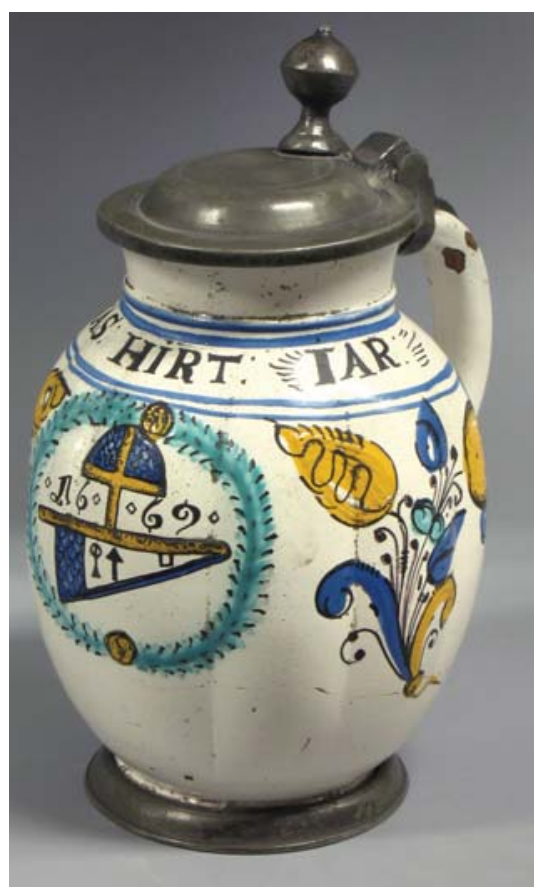

Fig. 11. Jug with the inscription IERMIAS :HIRT: IAR 1669 and a cloth-maker's emblem. Inv. n. KER 21240.

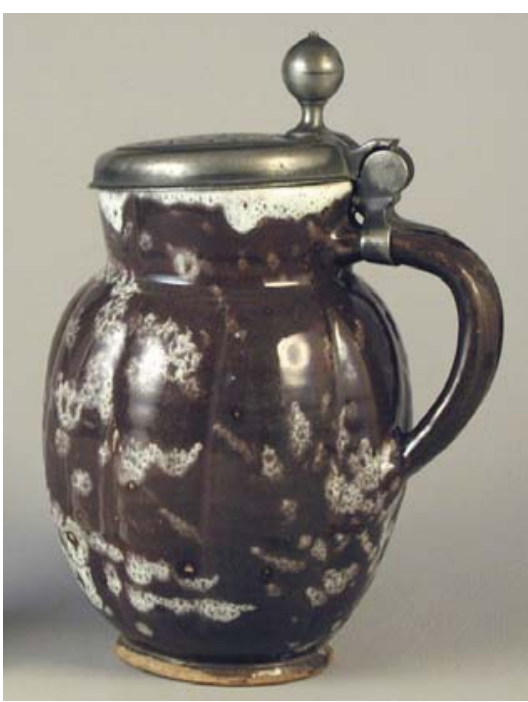

Fig

Fig. 13. Jug with manganese glazing and white marbling, third quarter of the $17^{\text {th }}$ century. Inv. n. KER 26343. 


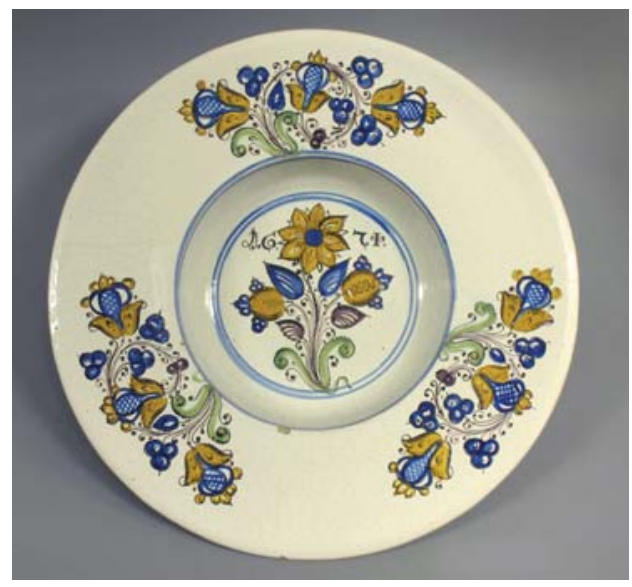

Fig. 14. Bowl with floral motifs from 1671. Inv. n. KER 20484.

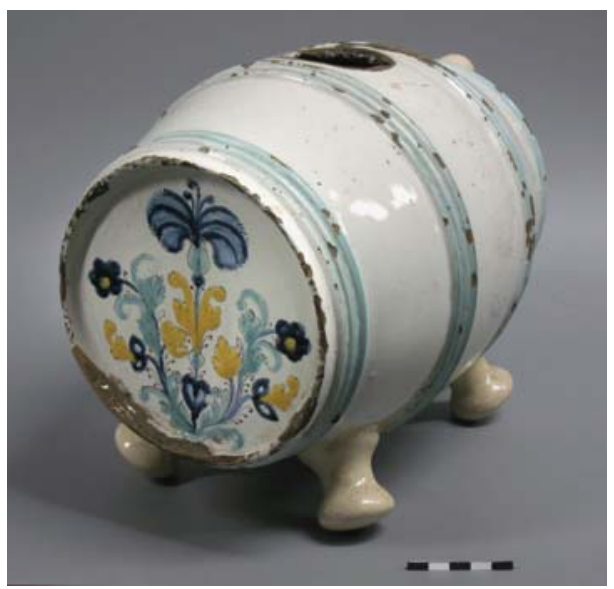

Fig. 15. Keg decorated on the front with floral decor, first half of the 17th century. Inv. n. KER 23702.

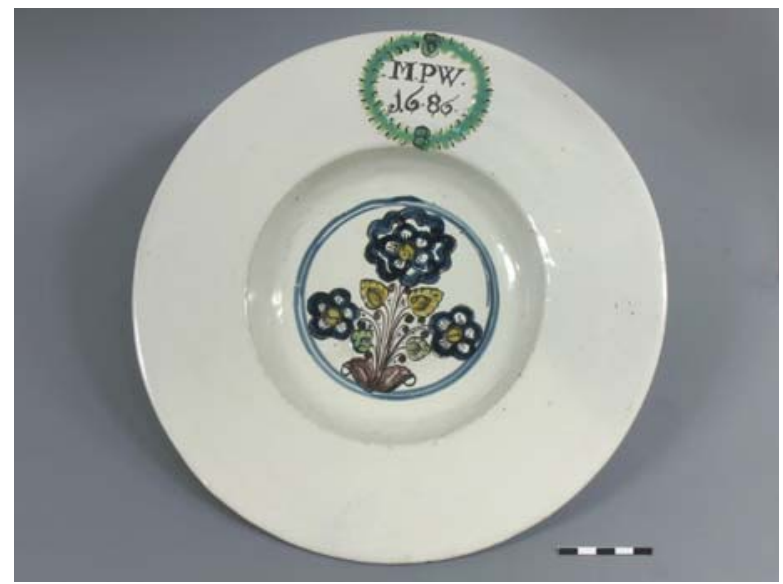

16. Bowl with the initials MPW and the date 1686 on the edge and a floral motif on the bottom. Inv. n. KER 20386. 


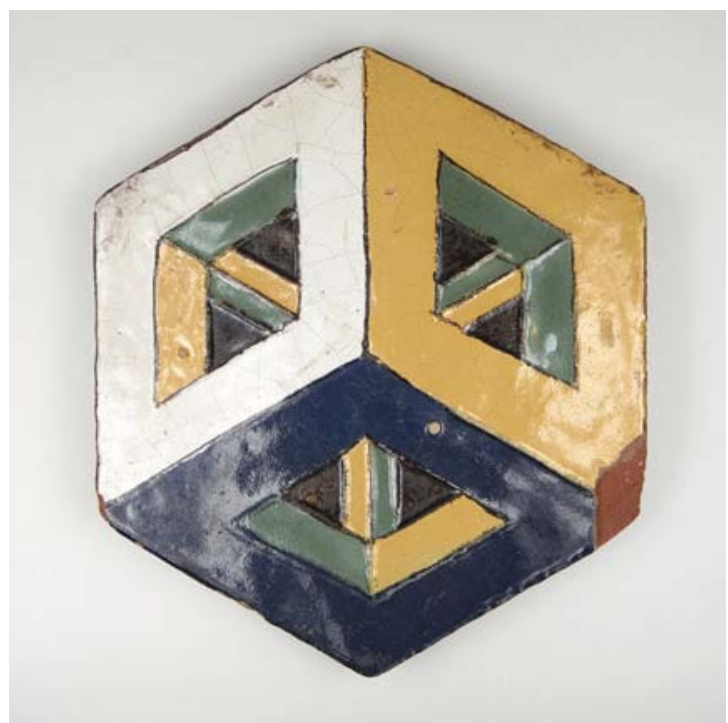

Fig. 17. Hexagonal tile, from a workshop in Farkašín (today Vlčkovce), third quarter of the $17^{\text {th }}$ century. Inv. n. KER 20462.

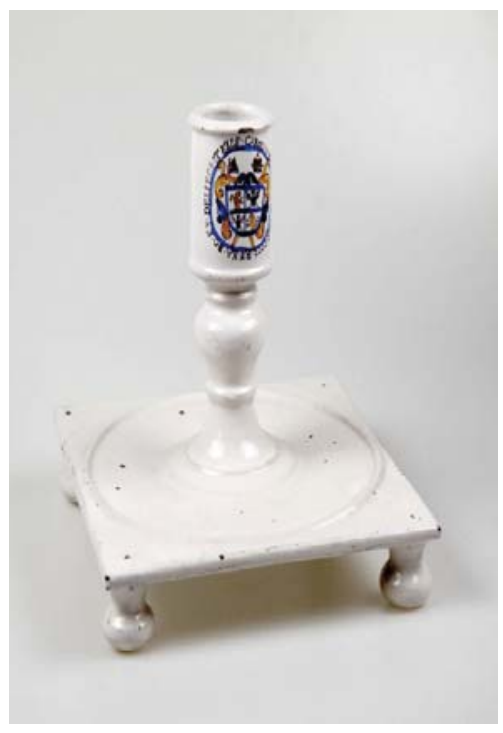

Fig. 18. Candle-stick with the emblem of bishop Karl of Liechtenstein, third quarter of the $17^{\text {th }}$ century. Inv. n. KER 20585.

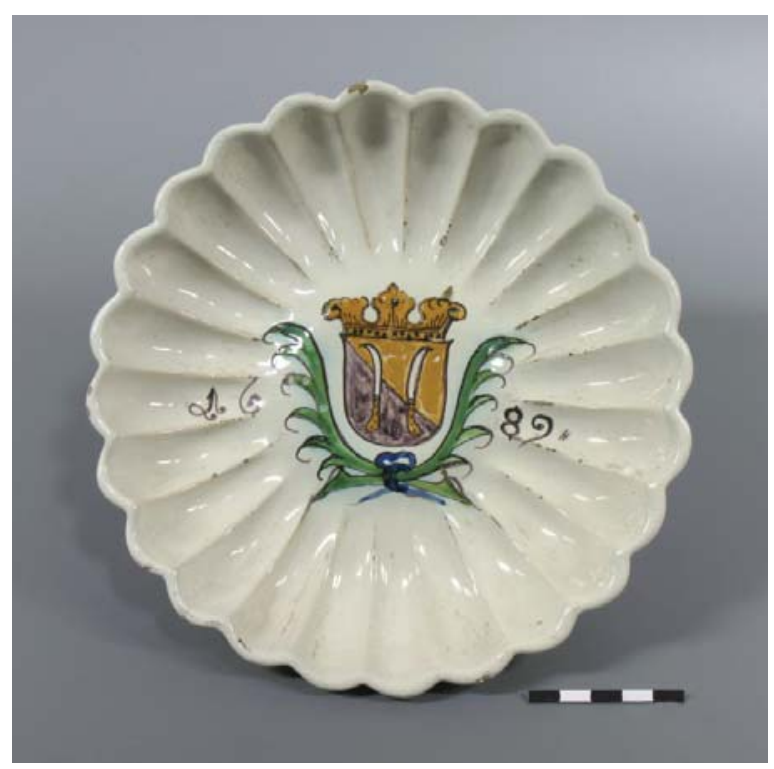

Fig. 19. Round, ribbed bowl on a leg with the Dietrichstein emblem from 1689, one of the first examples of Anabaptist faience in the collection of the Francis Museum, the predecessor of today's Moravian Museum. Inv. n. KER 20407. 


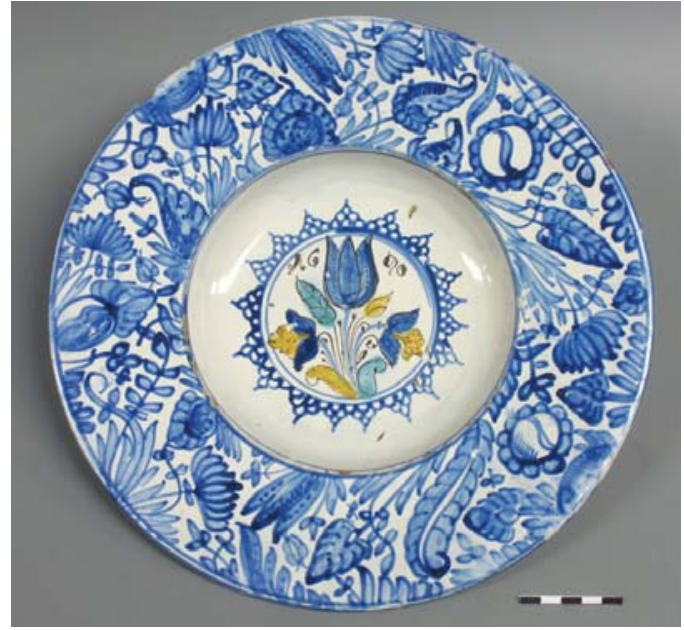

Fig. 20. Bowl with a floral motif and the date 1690 on the bottom and blue entwined décor on the edge. Inv. n. KER 20400.

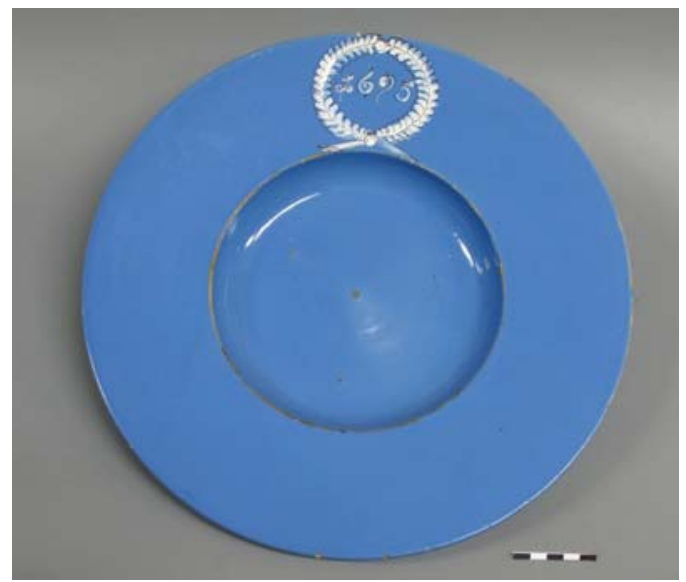

Fig. 22. Plate with blue glazing and a white wreath with the date 1695 on the edge. Inv. n. KER 20469.

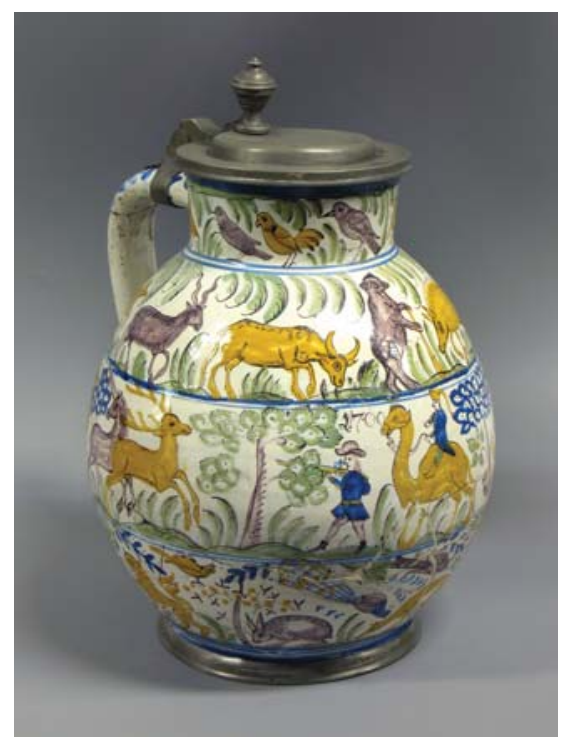

Fig. 21. Jug decorated with fable motifs from 1700 .

Inv. n. 20342.

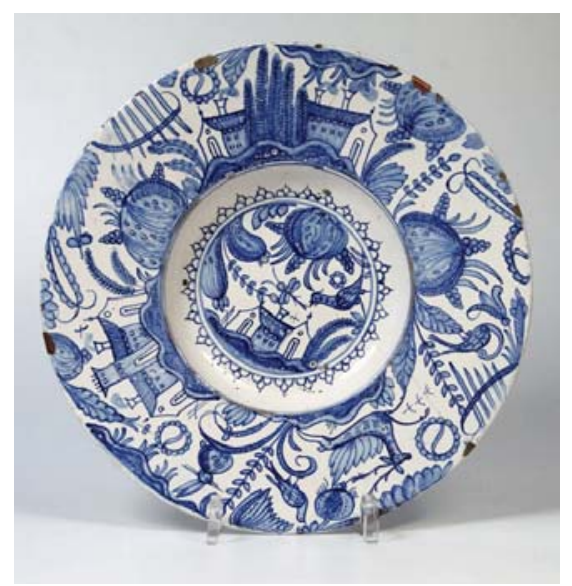

Fig. 23. Plate with blue entwined decor, end of the $17^{\text {th }}$ century. Inv. n. KER 20486. 


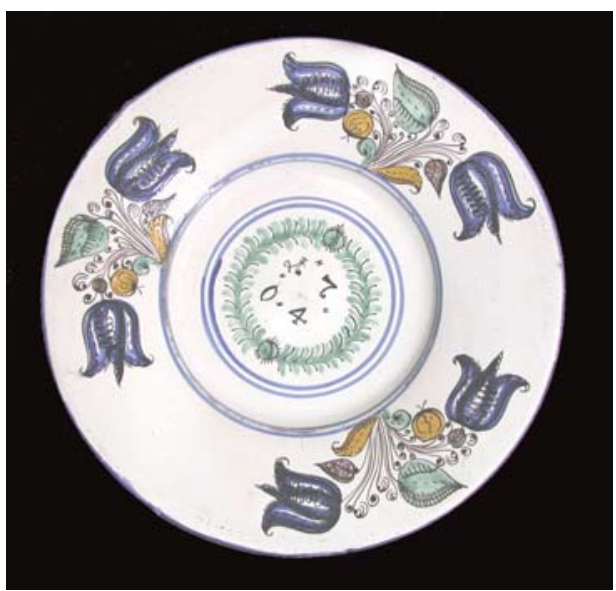

Fig. 24. Plate with floral motif of blue tulips from 1704 . Inv. n. 24685.

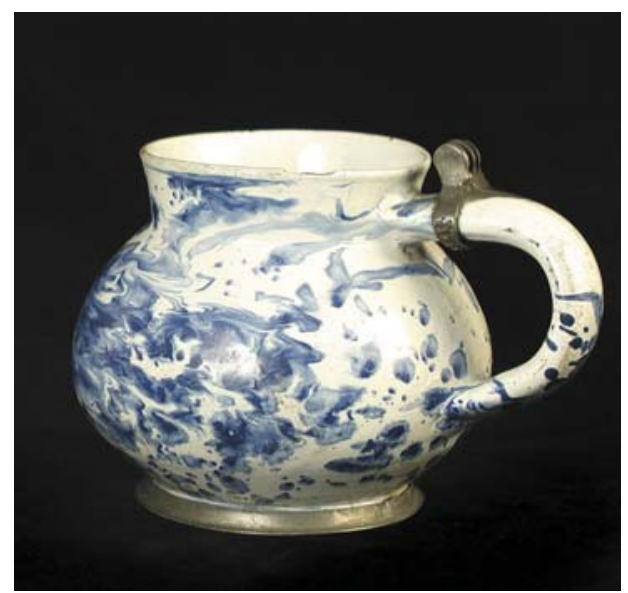

Fig. 25. Jug with white glazing and blue marbling, beginning of the $18^{\text {th }}$ century. Inv. n. KER 20460.

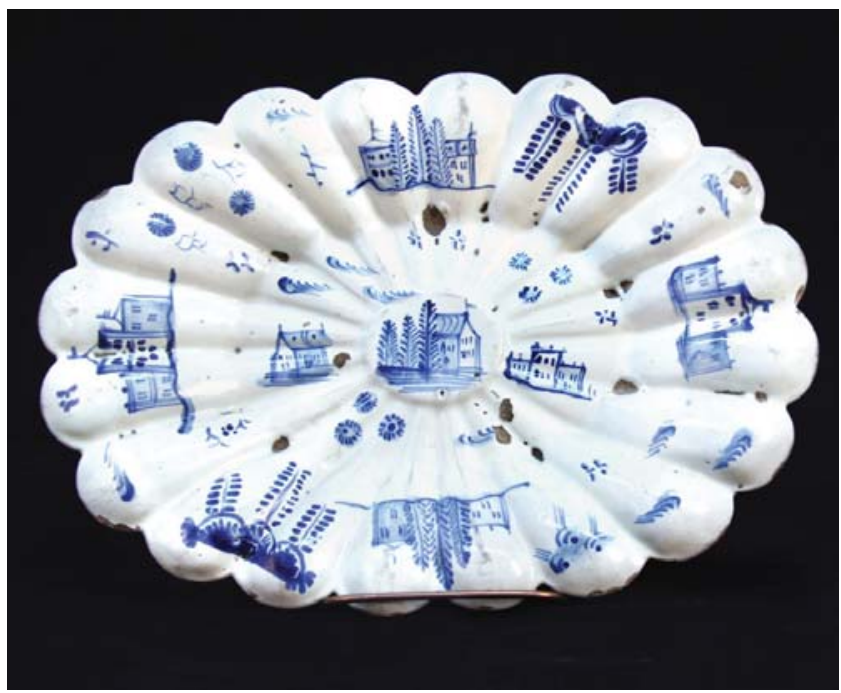

Fig. 26. Oval, ribbed tray on a leg with blue decor, beginning of the $18^{\text {th }}$ century. Inv. n. KER 20417. 


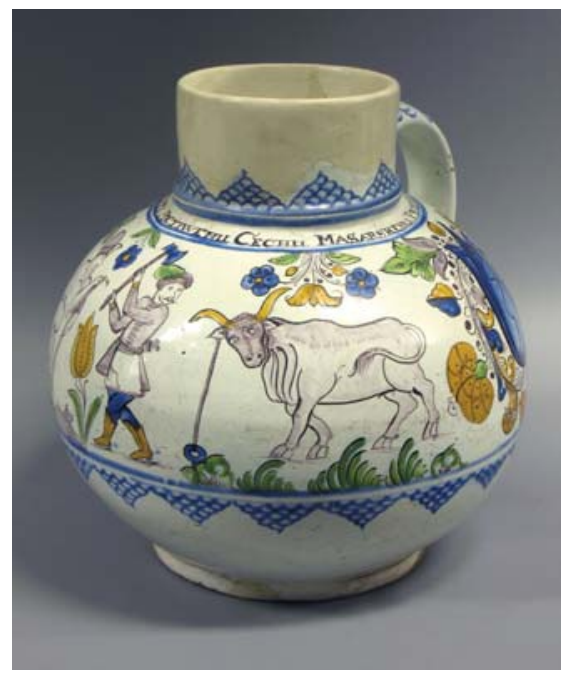

Fig. 27. Jug from 1718 made for the butchers' guild in Púchov (the inscription on the neck TEN TO ZBANNALEZI POCTIWEMU CECHU MASARSKEMU PRI MNESTE PUCHOVE). Inv. n. KER 20600.

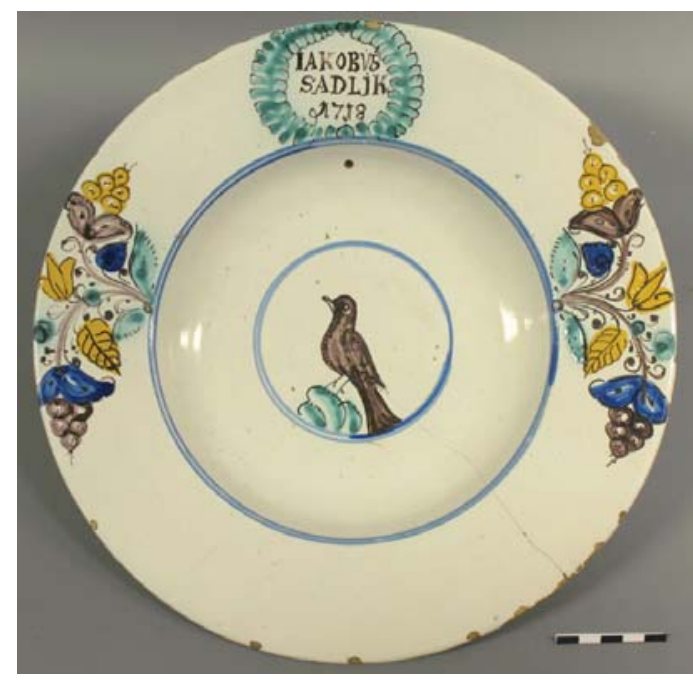

Fig. 28. Plate with a bird motif and the inscription JAKOBVS SADLIK 1718, probably from Nové Hvězdlice (Vyškov district), evidence of the start of a new stage of faience production in Moravia. Inv. n. KER 26590.

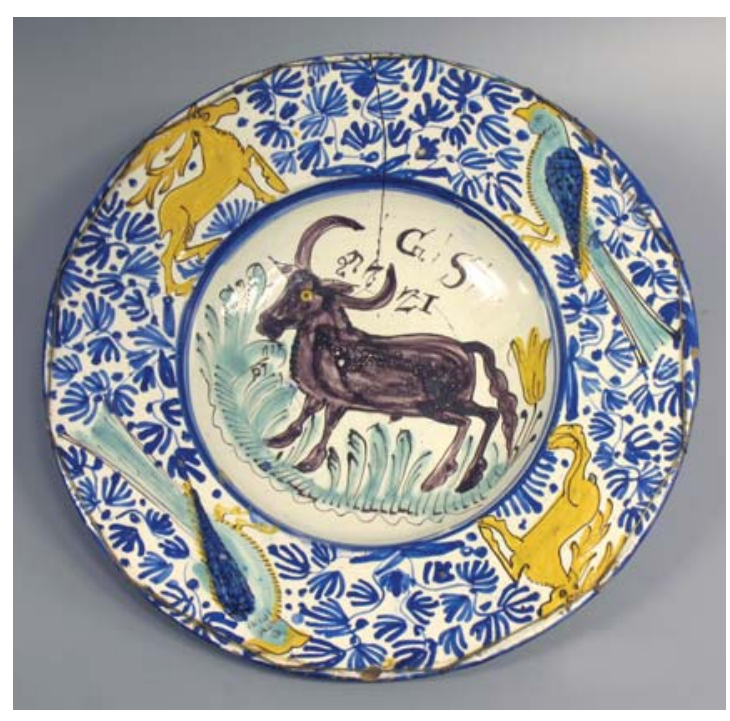

Fig. 29. Plate with a bull motif, the initials GS and the date 1721 . Inv. n. KER 20479.

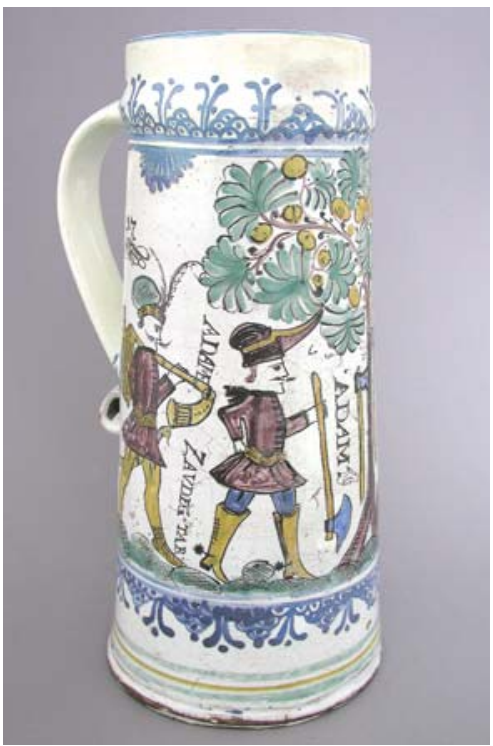

Fig. 30. Tankard with a depiction of mountain outlaws from 1726. Inv. n. KER 20337. 